\title{
Analysis on carbon emission reduction path and expected effect of inland river ships in China
}

\author{
Kun Li, Wendi Liu, Fangfang Jiao, Yongbo Ji \\ China Waterborne Transport Research Institute, Beijing 100088, China
}

\begin{abstract}
In order to systematically study the carbon emission reduction path suitable for China's inland river ships, this paper analyzes the actual situation of China's inland river ships ' operation scale, fleet structure, fuel consumption, etc., and combines the development of domestic and foreign carbon emission reduction technologies and the ship's own operating characteristics. Carbon emission reduction technology paths for China's inland river ships have been proposed in this paper, which includes different tonnage classes, different ship ages, and different types of river ships. Also, the expected application effects of each technology path are analyzed in depth in this paper. The research results can give a certain support for the implementation of carbon emission reduction in China's shipping industry.
\end{abstract}

\section{Introduction}

In recent years, China has continuously promoted the adjustment of the transportation structure, vigorously promoting the transfer of bulk cargo and medium and long-distance cargo to more environmentally friendly and green water transportation. While contributing to the realization of China's dual carbon goals by reducing the overall carbon emissions of the transportation industry, it is imperative to develop green and low-carbon technologies that adapt to China's specific national conditions(Hou et al.,2013) and future shipping emission requirements to promote the green and low-carbon transition of shipping(Li et al.,2013).

\section{Current situation of inland river ships in China}

According to incomplete statistics, As shown in Figure 1 and 2,China has 118,305 million inland river ships, including 105,225 freight ships, and 13,080 passenger ships, The tonnage and age structures of ships, are shown in Table 1 and Table 2. According to survey estimates, the annual fuel consumption of inland river ships is about 7.0168 million tons, of which the annual fuel consumption of freight ships is $6,814,200$ tons, and the annual fuel consumption of passenger ships is 132,600 tons.

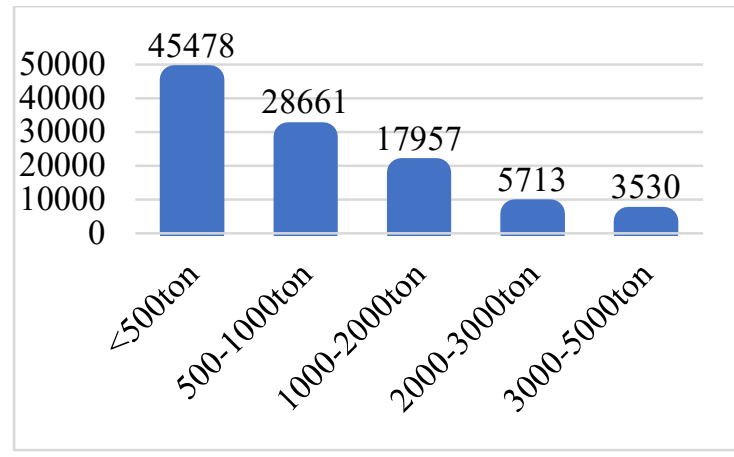

Figure 1. Statistics of the number of inland river freight ships of different tonnage classes

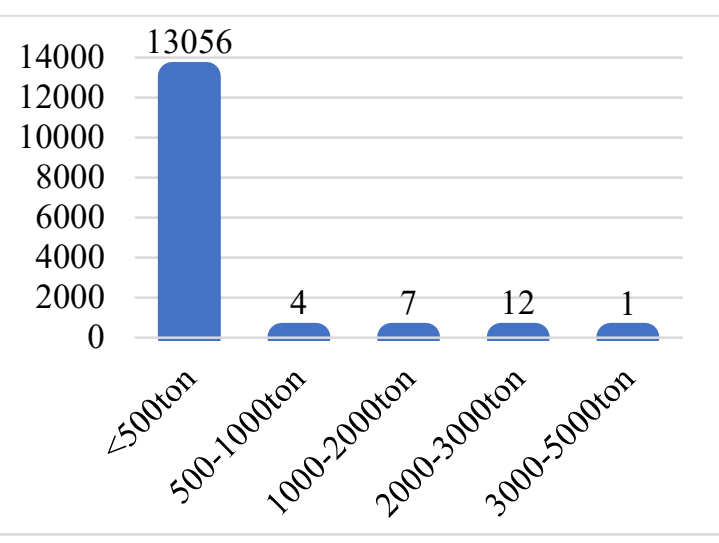

Figure 2. Statistics on the number of inland river passenger ships of different tonnage classes 
Table 1. Estimated fuel consumption of different tonnages of inland river freight ships

\begin{tabular}{|c|c|c|}
\hline DWT & $\begin{array}{c}\text { Estimated } \\
\text { annual fuel } \\
\text { consumption per } \\
\text { vessel(tons/year) }\end{array}$ & $\begin{array}{c}\text { Estimated } \\
\text { total fuel } \\
\text { consumption } \\
\text { (tons/year) }\end{array}$ \\
\hline$<500$ & 15 & 682170 \\
\hline $500-1000$ & 35 & 1003135 \\
\hline $1000-2000$ & 70 & 1256990 \\
\hline $2000-3000$ & 120 & 685560 \\
\hline $3000-5000$ & 200 & 706000 \\
\hline $5000-8000$ & 400 & 971600 \\
\hline $8000-$ & 800 & 479200 \\
\hline 10000 & 1200 & 1029600 \\
\hline$>10000$ & & $\mathbf{6 8 1 4 2 5 5}$ \\
\hline total & &
\end{tabular}

Table 2. Estimated fuel consumption of different tonnage classes of inland river passenger ships

\begin{tabular}{|c|c|c|}
\hline DWT & $\begin{array}{c}\text { Estimated } \\
\text { annual fuel } \\
\text { consumption per } \\
\text { vessel (tons/year) }\end{array}$ & $\begin{array}{c}\text { Estimated } \\
\text { total fuel } \\
\text { consumption } \\
\text { (tons/year) }\end{array}$ \\
\hline$<500$ & 10 & 130560 \\
\hline $500-1000$ & 30 & 120 \\
\hline $1000-2000$ & 80 & 560 \\
\hline $2000-3000$ & 100 & 1200 \\
\hline $3000-5000$ & 200 & 200 \\
\hline$>5000$ & 500 & 0 \\
\hline Total & & $\mathbf{1 3 2 6 4 0}$ \\
\hline
\end{tabular}

\section{Carbon emission reduction path and expected effect of inland river ships}

Facing the requirements of the waterway transportation industry to achieve the carbon peaking target, the shipping industry is actively seeking various feasible technological paths to achieve the ultimate carbon peaking target and carbon neutral vision. At present, in addition to the carbon trading market mechanism and carbon capture and storage (CCS), the main measures that are relatively mature and operable that can be used to reduce carbon in the waterway transportation industry include: application of low-carbon, zero-carbon new energy or clean Energy, accelerate the elimination of dismantling old ships, continue to promote large-scale ships; innovate and optimize the transportation organization model, etc.

\subsection{Promote the application of new energy and clean energy to accelerate the adjustment of energy structure}

Reducing the application of traditional fuels for ships and increasing the proportion of low-carbon clean energy such as LNG, methanol, batteries, fuel cells (including hydrogen, etc.) on ships is the most fundamental and effective solution to reduce carbon dioxide emissions from ships. LNG is currently the most mature low-carbon alternative energy source for ships, and battery is a relatively mature zero carbon alternative energy. It is expected that LNG and battery will be the main contributors to inland water ships to achieve " peaking carbon dioxide emissions " in 2030.

According to "General Principles of Comprehensive Energy Consumption Calculation" (GB/T2589-2020) and "Provincial Greenhouse Gas Inventory Compilation Guide" (NDRC Climate (2011) No. 1041), the calculation of carbon dioxide emission coefficients for different energy sources is shown in Table 3.

Table 3. Reference Coefficients of Diesel and LNG (Liquefied Natural Gas) Carbon Emissions

\begin{tabular}{|c|c|c|c|c|c|}
\hline $\begin{array}{c}\text { E } \\
\text { ne } \\
\text { rg } \\
\text { y } \\
\text { na } \\
\text { m } \\
\text { e }\end{array}$ & $\begin{array}{c}\text { Aver } \\
\text { age } \\
\text { low } \\
\text { calori } \\
\text { fic } \\
\text { value }\end{array}$ & $\begin{array}{c}\text { Conver } \\
\text { ted into } \\
\text { standa } \\
\text { rd coal } \\
\text { factor }\end{array}$ & $\begin{array}{c}\text { Carbon } \\
\text { content } \\
\text { per } \\
\text { calorific } \\
\text { value (ton } \\
\text { carbon/TJ } \\
\text { ) }\end{array}$ & $\begin{array}{c}\text { Car } \\
\text { bon } \\
\text { oxid } \\
\text { atio } \\
\text { n } \\
\text { rate }\end{array}$ & $\begin{array}{c}\text { carbo } \\
\text { n } \\
\text { dioxid } \\
\text { e } \\
\text { emissi } \\
\text { on } \\
\text { factor }\end{array}$ \\
\hline $\begin{array}{l}\text { Di } \\
\text { es } \\
\text { el }\end{array}$ & $\begin{array}{c}42 \\
705 \\
\mathrm{~kJ} / \mathrm{kg}\end{array}$ & $\begin{array}{c}1.4571 \\
\mathrm{kgce} / \mathrm{kg}\end{array}$ & 20.2 & 0.98 & $\begin{array}{c}3.0998 \\
\mathrm{~kg}- \\
\mathrm{co} 2 / \mathrm{kg}\end{array}$ \\
\hline $\begin{array}{l}\mathrm{L} \\
\mathrm{N} \\
\mathrm{G}\end{array}$ & $\begin{array}{c}3223 \\
8 \\
\mathrm{~kJ} / \mathrm{m} 3 \\
\sim 389 \\
79 \\
\mathrm{~kJ} / \mathrm{m} 3\end{array}$ & $\begin{array}{c}1.1000 \\
\mathrm{kgce} / \mathrm{m} \\
3 \sim \\
1.3300 \\
\mathrm{kgce} / \mathrm{m} \\
3 \\
\end{array}$ & 15.3 & 0.99 & $\begin{array}{c}1.7905 \\
\sim \\
2.1649 \\
\mathrm{~kg}- \\
\mathrm{co} 2 / \mathrm{kg}\end{array}$ \\
\hline
\end{tabular}

According to calculations, when LNG is used as a ship fuel, theoretically, natural gas with the same calorific value can reduce carbon dioxide emissions by about $30 \%$ compared with diesel. Considering that the existing technology of natural gas engines is not very mature, there are still $\mathrm{CH} 4$ fugitive emissions. The ability to reduce greenhouse gas ( $\mathrm{GHG}$ ) emissions has been weakened to a certain extent, and the overall effect of reducing emissions is currently about $10 \%-20 \%$.

Electric ships use batteries as their power source, which has the characteristics of "zero emission and zero pollution". Compared with the use of diesel, it can achieve zero carbon dioxide emission and achieve up to $100 \%$ GHG benefits.

Considering the technical maturity, endurance, ship space demand, cost and other factors of LNG and battery, combined with the characteristics of Chinese inland ships, it is recommended that cargo ships less than $1000 \mathrm{dwt}$ and all passenger ships be transformed into electric ships powered by battery through elimination, renewal, dismantling, new construction and reconstruction of existing ships; LNG power is adopted for the elimination and renewal of cargo ships of 1000 DWT and above, dismantling and new construction, and reconstruction of existing ships.

Cargo ship. 50\% of ships under 1,000 dwt are upgraded to electric ships. According to Table 1, the amount of fuel 
can be replaced by 842,700 tons; according to Table 3 , carbon dioxide emission reductions of 2,612,200 tons can be achieved. $50 \%$ of ships above $1,000 \mathrm{dwt}$ are upgraded to LNG-powered ships. According to Table 1, the amount of fuel can be replaced by 2.5645 million tons. According to Table 3 and SGMF's forecast, the 22\% GHG benefit of replacing fuel with natural gas can be achieved, which can reduce carbon emissions by $1,768,800$ tons.

Passenger ships. 50\% of passenger ships are updated to electric ships. According to Table 2, the amount of fuel can be replaced by 66,300 tons. According to Table 3 , carbon emissions can be reduced by 205,500 tons.

By $2030,50 \%$ of the existing inland river cargo ships and passenger ships will be upgraded to LNG-powered ships and electric ships, and a total of 4,586,500 tons of carbon emissions can be reduced.

\subsection{Implement the elimination and dismantling of old ships to build new ones, and promote the optimization of the fleet structure}

Old ships have the characteristics of high energy consumption, low energy efficiency, and relatively high pollutant emissions. In addition to scrapping a part of the ships according to the prescribed natural life limit, through economic encouragement of old transport ships to be scrapped in advance and renewed into new energy clean energy ships, can achieve dual carbon reduction capabilities: Firstly, with the continuous development of China's shipbuilding industry, ship products have achieved rapid upgrades, especially the energy efficiency of China's ship engines during the "13th Five-Year Plan" period, and the unit carbon emission intensity has decreased; secondly, Second, the old ships will be demolished and newly built into new energy and clean energy ships, with low or even zero carbon emission intensity compared with traditional diesel.

According to the survey, during the 13th Five Year Plan period, the energy efficiency level of ship engines continued to improve, and the unit carbon emission intensity gradually decreased. After the old ships were eliminated and disassembled, the energy efficiency level of engines increased by about $20 \%$ compared with the old ships, which means that the carbon emission intensity decreased by $20 \%$.According to statistics, the total number of ships of different tonnages built before 2015 is 117,739. According to Table 1 and Table 2, the total fuel consumption of ships is $6,873,900$ tons. After the elimination, dismantling and new construction, the amount of fuel saved is 1,374,700 tons. Table 3 estimates that the carbon emission reduction can be achieved by 4.2615 million tons.

\subsection{Promote the large-scale development of ships and continuously improve the energy efficiency of ships}

The speed of large-scale inland river ships depends on the two major factors of the large-scale new and updated ships(Jia et al.,2007). The large-scale addition of new ships is mainly due to the improvement of infrastructure, market demand and market competition, and the adjustment of the transportation capacity structure will accelerate the update(Jia et al.,2015). Promoted the historical process of large-scale. Since the beginning of the new century, China's inland river ships have continued to grow in size. In 2020, the average dwt of inland river motor cargo ships will reach 1443 tons, As shown in Figure 3,which is 18.4 times that in 2000 and 2.7 times that in 2010(Jia et al.,2019).

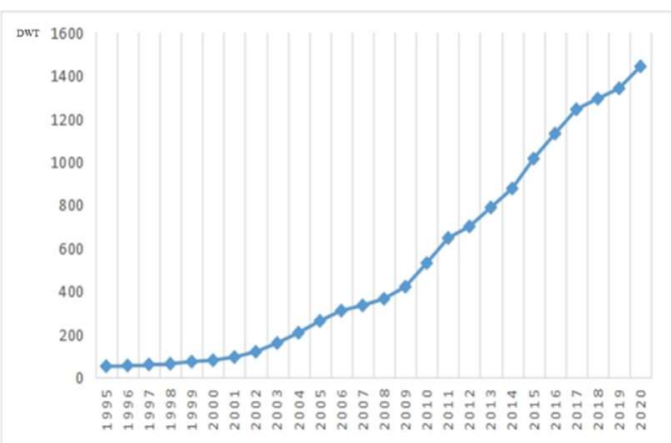

Figure 3 Average deadweight of inland water motorized cargo ships

The increase in the size of inland watercrafts has made the increase in total power slower than the rate of increase in total deadweight. For example, the power of a dry bulk carrier of about $1,000 \mathrm{dwt}$ is about 300 kilowatts, and that of a dry bulk carrier of about 2,000 dwt is about 400 kilowatts. In 2019, the total deadweight of inland waterdriven cargo ships was 10.17 times that of 2000 and 1.95 times that of 2010 , while the total power was only 4.29 times that of 2000 and 1.33 times that of 2010 . It can be seen from Figure 4 that the average power per deadweight tons of inland water-driven cargo ships has been declining year by year due to the large-scale ships. There is a linear relationship between ship fuel consumption and power under other conditions unchanged, so it can be explained that under the development trend of large-scale ships, if the ship's total deadweight remains the same, the ship's total fuel consumption will decrease.

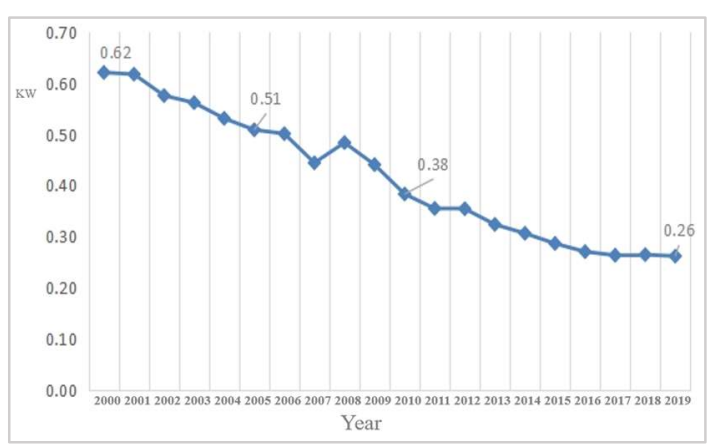

Figure 4 Average power change per deadweight ton of inland water-driven cargo ships

At present, China's inland river infrastructure construction continues to increase, infrastructure improvement and long-distance transportation demand growth, there is still a large potential for large-scale ships. According to the current large-scale rate of newly built cargo ships, China's inland river motor cargo ships will be estimated by 2030 . The average tonnage reaches about 2000t. According to 
the calculations of Data for 2019, every increase of 100 tons in average deadweight of inland river motor cargo ships can achieve a power drop of about 0.005 kilowatts per deadweight ton. It is estimated that the power per deadweight ton of inland river motor cargo ships in 2030 will decrease by 0.025 kilowatts compared with 2020 , a decrease of approximately Is $9.5 \%$. Due to the linear relationship between fuel consumption and power, the carbon dioxide emission reduction per deadweight ton of ship capacity that can be brought about by the large-scale ship by 2030 is about $9.5 \%$. According to Table 1 and Table 2, the fuel consumption of ships and the calculation in Table 3 can achieve a carbon emission reduction of 2.0663 million tons.

\subsection{Optimize the organization mode of ship transportation and improve the level of transportation efficiency}

The improvement of ship transportation organization efficiency with emission reduction contribution is mainly reflected in reducing empty driving, berthing and speed optimization. The organizational efficiency of ship transportation can be reflected by the annual cargo turnover that can be completed per DWT. In 2019, as shown in Figure 5,the average cargo turnover of inland ships per DWT will be 12500 ton-kilometer, which is 1.57 times that in 2010 and 2.07 times that in 2003. (Affected by the epidemic situation and the adjustment of statistical data, the turnover of inland river goods decreased in 2020.)

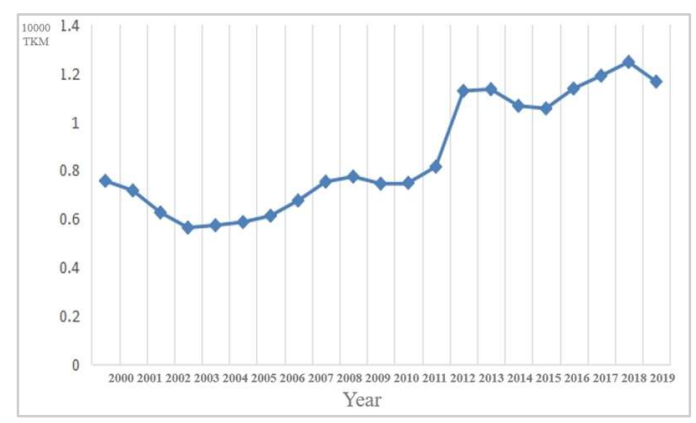

Figure 5 The average capacity of inland ships per deadweight ton completed and the change in cargo turnover

However, according to market research, the current empty rate of inland water ships is still relatively high. In the future, with the improvement of logistics technology such as freight platform economy, the efficiency of transportation organization can be effectively improved. With the development of port automation, the improvement of port efficiency will also reduce the number of ships waiting for berths. Comprehensive consideration of reducing the operating turnover efficiency of ships such as empty ships and awaiting berths. It is estimated that the completed cargo turnover per deadweight ton in 2030 can reach 13,500 tons. The sailing time of ships carrying cargo is about 80 days per year, accounting for about $27 \%$ of the ship's operating time. In this scenario, the improvement of transportation organization efficiency can bring about $8 \%$ of carbon dioxide emission reduction per deadweight ton ship capacity. According to the fuel consumption of ships in Table 1 and Table 2, and according to Table 3, the carbon emission reduction can be achieved by 1.74 million tons. Speed optimization refers to the use of assisted driving technology and intelligent ship technology to rationally optimize the speed of each period according to the turnaround time, so as to achieve fuel saving and emission reduction. However, when the supply of goods is sufficient, it may be possible to increase the speed to speed up the turnover of the ship. The scenario is more difficult to predict, so here No quantitative analysis, but the overall intelligent technology will promote ship emissions reduction in terms of speed optimization and intelligent energy efficiency.

\section{Conclusion}

The structure of China's inland watercraft is complex. The path selection of ship carbon emission reduction should comprehensively consider factors such as economic development, infrastructure construction, ship type, tonnage, route, ship age, etc., combined with shipping carbon reduction targets and carbon reduction technology maturity and economy, etc., this paper proposes four Different paths include "promoting the application of new energy and clean energy", "accelerating the adjustment of energy structure, implementing the elimination of old ships and building new ones", "promoting the optimization of fleet structure and promoting the development of large-scale ships", and "continuously improving ship energy efficiency Level, optimize the ship transportation organization model, and improve the level of transportation efficiency. "These four different technological paths have their own characteristics. The selection of carbon emission reduction technology paths that are suitable for ships in the region must be tailored to local conditions and lay a solid foundation for China to achieve its dual-carbon goals.

\section{Acknowledgments}

Fund Project: This research is supported by the research project on the safe operation guidelines and technical standards of the shore power supply of international sailing ships, the special self-help project for the innovation of green and intelligent inland ships and the special project of green ecological and environmental protection ship engineering.

\section{References}

1. Li Jing and Li Ruiyu. (2013). Research on the impact of carbon tax on China's shipping industry and Its Countermeasures. Navigation technology, 000(005), 67-69.

2. Hou guiguang, Xu Yi ,Jia Jielin and Lu jing. (2013). Quantitative study on the correlation mechanism between energy structure adjustment and carbon dioxide emission. Annual meeting of Chinese society of Environmental Sciences 
3. Jia Dashan.(2007). Exploration on the development strategy of water transportation in China. Dalian Maritime University Press

4. Jia Dashan and Ji Yongbo.(2015). Inland advantage strategy. People's Communications Press

5. Jia Dashan ,Ji Yongbo and Jiao Fangfang.(2019). Vigorously promote ship standardization and promote the high-quality development of inland ships. China water transportation (7). 